\title{
A TECHNICAL AND ECONOMIC EVALUATION OF A SMALL- SCALE COCONUT OIL EXPELLER OPERATION IN THE COOK ISLANDS ${ }^{1)}$
}

\author{
J. C. Barrett T W. Hammonds, and R. V. Harris
}

\begin{abstract}
Small-scale processing of copra was demonstrated to be technically feasible and potentially very profitable in the Cook Islands using equipment comprising a copra chopper, a screw press and a filter press. At through-puts close to $65 \mathrm{~kg}$ per hour, yields of ciarified oil and copra cake were around 55 per cent and 40 per cent respectively, on a weight basis. A consumer survey indicated that coconut oil could be marketed as a cooking oil to substitute for imported vegetable oils; potential use in soap manufacture was also identified, while copra cake was readily marketed for animal feeding. For an initial establishment cost of just under NZS 100,000 the f-mancial internal rate of return for investment in small-scale copra processing in the Cook Islands, provided that all output can be marketed, is calculated as 49 per cent, which is very attractive. Prospects for the success of similarventures at locations elsewhere in the Pacific are promising.
\end{abstract}

\section{INTRODUCTION}

Coconut cultivation and production of copra for export are major economic activities for many island communities in the Pacific Ocean. However, the value of the copra to the exporting country is invariably reduced by international transport costs. Edible oil and livestock feed are imported, usually at a high price due to further transport costs and traders' margins.

If these often remote and isolated communities had access to small-scale copra processing units they would be able to produce edible oil and livestock feed for local consumption to replace these expensive imports. Moreover, employment opportunities would be created and value added to agricultural production.

Although studies on. the small scale processing of-oilseeds in general have been numerous, published work specifically dealing with copra is limited (1-3).

The Tropical Development and Research Institute (TDRI) has worked for some years on. small-scale oilseed processing (4) and has collaborated with a UK engineering company in the development of a small powered screw press with a capacity in the region of $25-50 \mathrm{~kg} / \mathrm{hr}$. Previous work (5) has demonstrated the unit's potential for processing sunflowerseed and this has culminated in the establishment of a number of Cooperative-owned processing facilities in Central Africa.

More recent work at TDRI in the UK has shown that the screw press, together with certain items of ancillary equipment, also operates efficiently on copra. With copra of an appropriate quality, the coconut oil produced would be suitable for human consumption. An opportunity arose, through a project funded by UNIDO, to investigate the potential for such small-scale processing in the Cook Islands.

*Tropical Developinent and Research Institute, 56/62 Gray's Inn Road, London WC1 8LU, England. EQUIPMENT REQUIREMENTS 
The basic equipment necessary to produce coconut oil from copra comprises a chopper to break down the copra pieces into suitably sized fragments and a screw press to continuously expel oil, giving copra cake as the residue.

Since the efficiency of oil extraction is influenced by the moisture content, a heating stage may be necessary to further dry the copra. For small-scale ventures, where steam raising cannot be carried out econornically, equipment fired by bottled gas, fuel oil, or firewood is suitable.

Freshly produced crude oil has a dark cloudy appearance due to the presence of finely divided particulate matter. With some oils, eg sunflowerseed, this material will. settle out when the oil is allowed to stand undisturbed for a day or so, but with coconut oil a sufficiently clear oil cannot usually be obtained in this; manner, and it is then necessary to pass it through a filter press.

The equipment used in these trials (see footnote) comprised :

(a) Copra Chopper: Condux Cutting MM Type CS150/100-2, fitted with a 1 Omm screen.

(b) Seed Heater: Hander Seed Scorcher Type L, heated by a butane gas burner.

(c) Screw Press: Simon Rosedowns Mini 40 expeller, powered by a 6.7KW Petter PHI Diesel Engine, and fitted with an electrically driven vibratory feeder. This expeller comprises a wormshaft which rotates inside a closely fitting barrel composed of separate rings spaced apart by shim washers (see Figure 1).

(d) Filter Press: Edwards and Jones $406 \mathrm{~mm}$ x $406 \mathrm{~mm}$ Plate and Frame Press, with 6 filtration chambers (1.14 $\mathrm{m}^{2}$ filtration area), fitted with a Monopump MD 22 providing a flow rate of about 3 litres of oil a minute.

The equipment was sited in Avarua, Rarotonga, inside a warehouse with good ventilation, a large outside door for easy access, and a small room utilised as an office and store. Installation required the provision of electricity supplies to each unit, the construction of a hearth for the seed heater, a concrete plinth for the screw press, and bolting the chopper and filter press to the floor.

\section{Equipment Performance}

(a) Copra aopper : A steady throughput of about $160 \mathrm{~kg}$ per hour was easily achieved, provided the larger pieces were broken by hand before feeding to the mill. Over $90 \%$ of the copra was reduced to less than $0.5 \mathrm{~cm}^{3}$ in size.

(b) Seed Heater: Approximately $0.75 \mathrm{~kg}$ of butane gas was required to heat the furnace to $65^{\circ} \mathrm{C}$. Heating 1 tonne of copra to $65^{\circ} \mathrm{C}$ required about $12 \mathrm{~kg}$ of gas. The most convenient mode of operation was to heat the copra in $25 \mathrm{~kg}$ batches. This took about 15 to 20 minutes, and enabled the production of heated copra to match the requirements of the screw press. Heating reduced the moisture content of the chopped copra from 5.3 per cent to 3.7 per cent.

Footnote: Mention of a particular company does not imply a recommendation by TDRI of that company or its products to the exclusion of others which may be available. 
Figure 1

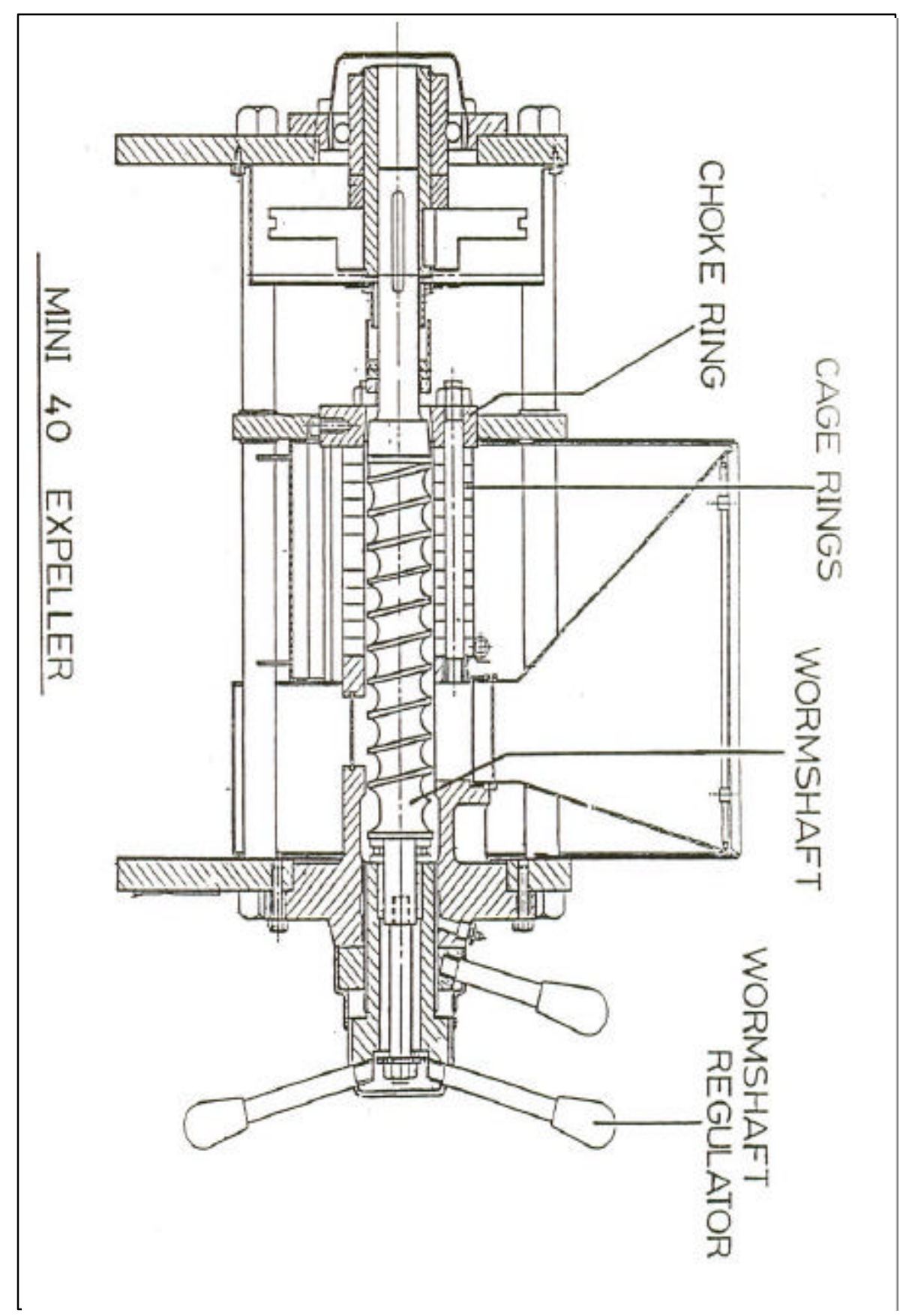

(c) Screw Press: Ten month old copra was utilised for commissioning purposes and preliminary determinations of performance. Fresh copra was used for the remainder of the trials, including the commissioning of the seed heater and preparing oil for the consumer survey. 
Table 1

Typical operational data for screw press

\begin{tabular}{|l|c|c|c|}
\hline & A & B & C \\
\hline Copra processed (kg) & 592 & 255 & 750 \\
Throughput (kg/hr) & 61.7 & 70.8 & 71.4 \\
Crude oil expelled (kg) & 357 & 148 & 433 \\
Process/Moisture loss (kg) & 255 & 99 & 280 \\
Crud Oil Extraction Rate (\%) & 10 & 8 & 37 \\
& 60.3 & 58.0 & 57.7 \\
\hline Projected Yields from 1 tonne copra & 603 & 580 & 377 \\
\hline Crude Oil (kg) & 380 & 388 & 373 \\
Oil Cake (kg) & & \\
\hline
\end{tabular}

Notes:

A : : 10 month old copra, moisture content $4.3 \%$, unheated.

B : Fresh copra, moisture content $5.3 \%$, unheated.

C : As B, copra heated to $65^{\circ} \mathrm{C}$ for $10-15$ mins before expelling.

Table 1 shows typical operational data for the screw press, with both old and fresh copra, and the effect of heating the fresh copra before expefling. As can be seen, old copra provides a slight ly better yield of oil than fresh, and no gain in oil extraction efficiency appears to be achieved by using the seed heater. However, both old and fresh copra had reasonably low moisture contents, 4.3 per cent and 5.3 per cent respectively. One of the purposes of heating copra prior to expelling is adjustment of moisture content When a batch of copra of moisture content 9.2 per cent was processed, the extraction efficiency was reduced from 58 per cent to 37 per cent. Thus in circumstances where copra moisture content is higher than 6-7 per cent it is probable that heating would be of benefit. However, it should be noted that copra with a moisture content of less than 2 per cent has proved difficult to process using the Mini 40 expeller. The optimum choke setting for the screw press, gave an oil cake thickness of about $1 \mathrm{~mm}$. Narrower choke settings resulted either in blockages or in. ex cessive amounts of solid material (f-mes) being e.Npelled with the oil, whilst wider settings led to lower oil yields. A number of spacer settings were tested during the trials and the most efficient, (in thousandths of an inch), close enough to inhibit production of fines yet providing good drainage of oil from the baffel, was found to be :

FEED END 30,3 0, 20, 10, 5, 5, 5, 5, 5, 5, 5 CHOKE END

The screw press operated smoothly at wonnshaft rotational speeds of 80 and 100 RPM, but at 110 RPM ex cessive vibration from the diesel engine became apparent and the level of vibration experienced above 110 RPM made operation at higher speed impractical. The rate of copra throughput varied according to wormshaft RPM, with hourly rates of $53 \mathrm{~kg}, 63 \mathrm{~kg}$ and $67 \mathrm{~kg}$ at $80 \mathrm{RPM}, 100$ RPM and 110 RPM, respectively.

Since similar yields of crude coconut oil per $100 \mathrm{~kg}$ of copra were obtained at all these speeds 100 RPM was selected as the optimum speed, consistent with vibration-free running and the fastest practical copra throughput per hour. Diesel fuel consumption of the screw press averaged 11.7 litres per tonne of copra processed. 


\section{Double pressing}

The expeller processed ground oilcake (ie the cake was re-expelled after passing through the chopper) at approximately $45 \mathrm{~kg}$ per hr to give a 19 per cent yield of crude oil. However, using oilcake the screw press was difficult to control, requiring constant adjustment of the choke to avoid blockages and to maintain a steady throughput. The screw press was also under such stress that one of the barrel rings fractured whilst processing oilcake. In contrast, no barrel rings failed during the processing of chopped copra.

Table 2 compares the single and double pressing operations and shows that although 7 per cent more crude oil is produced per unit weight of copra (and consequently 7 per cent less oilcake) the double pressing operation has a 35 per cent lower overall throughput.

In view of this much lower throughput, the increased difficulty in operating the screwpress, its hkely higher rate of wear and stress, and the ready market that exists for single press oilcake, it was concluded that double pressing was not a worthwhile operation in the Cook Islands.

Table 2

Comparison of throughputs and yields of typical single and double pressing operations

\begin{tabular}{|l|c|c|}
\hline & Single Pressing & Double Pressing \\
\hline First Press & 65 & 65 \\
Copra processed (kg) & 1 & 1 \\
Time taken (hour) & 39 & 39 \\
Crude oil produced (kg) & 24.7 & 24.7 \\
Oilcake produced (kg) & - & 24.7 \\
\hline Second Press & 33 \\
\hline Copra processed (kg) & - & 4.7 \\
Time taken (hour) & - & 20 \\
Crude oil produced (kg) & - & \\
Oilcake produced (kg) & \multicolumn{2}{|c|}{} \\
Overall Performance & 390 & 252 \\
\hline Copra processed in 6 hr & 234 & 169 \\
Operating day (kg) & 148 & 77 \\
Oil produced (kg) & 60 & 67.1 \\
Oilcake produced (kg) & 38 & 31 \\
Yield of crude oil (\%) & \multicolumn{2}{|c|}{} \\
Yield of oilcake (\%) & \multicolumn{2}{|c|}{} \\
\hline
\end{tabular}

(d) Filter Press : One day's production of about $200 \mathrm{~kg}$ of crude oil, produced from unheated copra, typically contained about $14 \mathrm{~kg}$ of solids in suspension but attempts to filter this oil immediately after expelling resulted in un-acceptably low filtration rates of about 0.5 litres per minute. If, however, the crude oil was aflowed to stand ovemight, about $9 \mathrm{~kg}$ of the suspended material settled out. The remainder, $5 \mathrm{~kg}$, could then be readily removed by the filter press with a flow rate initially at 3 litres of oil per minute, although slowly decreasing to 1 litre per minute as material accumulated on the filter cloths. 
Thus in clarifying the oil, two types of solid material were obtained, sediment from the overnight standing, and filter cake, the former containing about 80 per cent oil, the latter 42 per cent.

The sediment can be recycled through the screw press without difficulty, admixing it with the copra feedstock. However, a similar procedure for filter cake was less satisfactory. Finely divided solid materials, of which the filter cake is composed, reappeared in the expelled oil and adversely affected filter press performance. The most advantageous method of disposal for the filter cake appeared to be blending it uniformly with oilcake for sale as livestock feed.

However recycling of sediment should be approached with caution, particularly when edible use of the coconut oil is envisagdd, since free fatty acid levels in sediment can rise rapidly if reprocessing is not carried out within a day or so.

\section{Summary of operational procedures and technical performance}

The flow chart for small scale copra processing with the equipment specified earlier is shown in Figure 2.

The individual items of equipment used proved to be well matched with respect to relative capacity. The copra chopper could prepare sufficient for a day's requirements in about 21/2 hours. Although the seed heater performed satisfactorily its use was found to be unnecessary for Cook Island copra, similar yields of oil being obtained from both heated and unheated batches. Oil clarification was most satisfactorily achieved by allowing the larger particles to settle overnight (to produce a sediment that could be reprocessed with the copra through the screw press) and using the filter press; to remove the finer particles still in suspension. A day's partially clarified crude oil could be filtered the following day in about $21 / 2$ hours.

An 8 hour working day was operated along the lines shown in Figure 3 using a team consisting of one semi-skilled supervisor responsible for overall production, and two general labourers.

Yields and throughputs of such a system will clearly vary depending on copra quality, equipment maintenance and operator skill and care. The summary performance data presented in Table 3 are derived from the extensive series of trials caTried out during the project and are used in the later financial analysis.

Table 3

Yield and Throughput Summary

\begin{tabular}{|l|c|c|c|}
\hline & $\begin{array}{c}\text { Copra } \\
\text { Processed }\end{array}$ & $\begin{array}{c}\text { Clarified Oil } \\
\text { Marketed }\end{array}$ & $\begin{array}{c}\text { Oilcake } \\
\text { Marketed }\end{array}$ \\
\hline Per hour (kg) & 63 & 34 & 26 \\
$\begin{array}{l}\text { Per day (kg) } \\
\text { (see Figure } 3)\end{array}$ & 378 & $\begin{array}{c}206 \\
(=227 \text { litres }) \\
545\end{array}$ & 155 \\
per tonne copra (kg) & 1000 & $\begin{array}{c}(=600 \text { litres }) \\
56,700 \text { litres }\end{array}$ & 410 \\
Per year (Tonnes) & 94.5 & & 38.7 \\
(250 working days) & & & \\
\hline
\end{tabular}

Note: Assumes recycling of sediment through the expeller but disposal of filter cake by blending with oilcake.

Figure 2. Flow chart for small-scale Copra Processing 


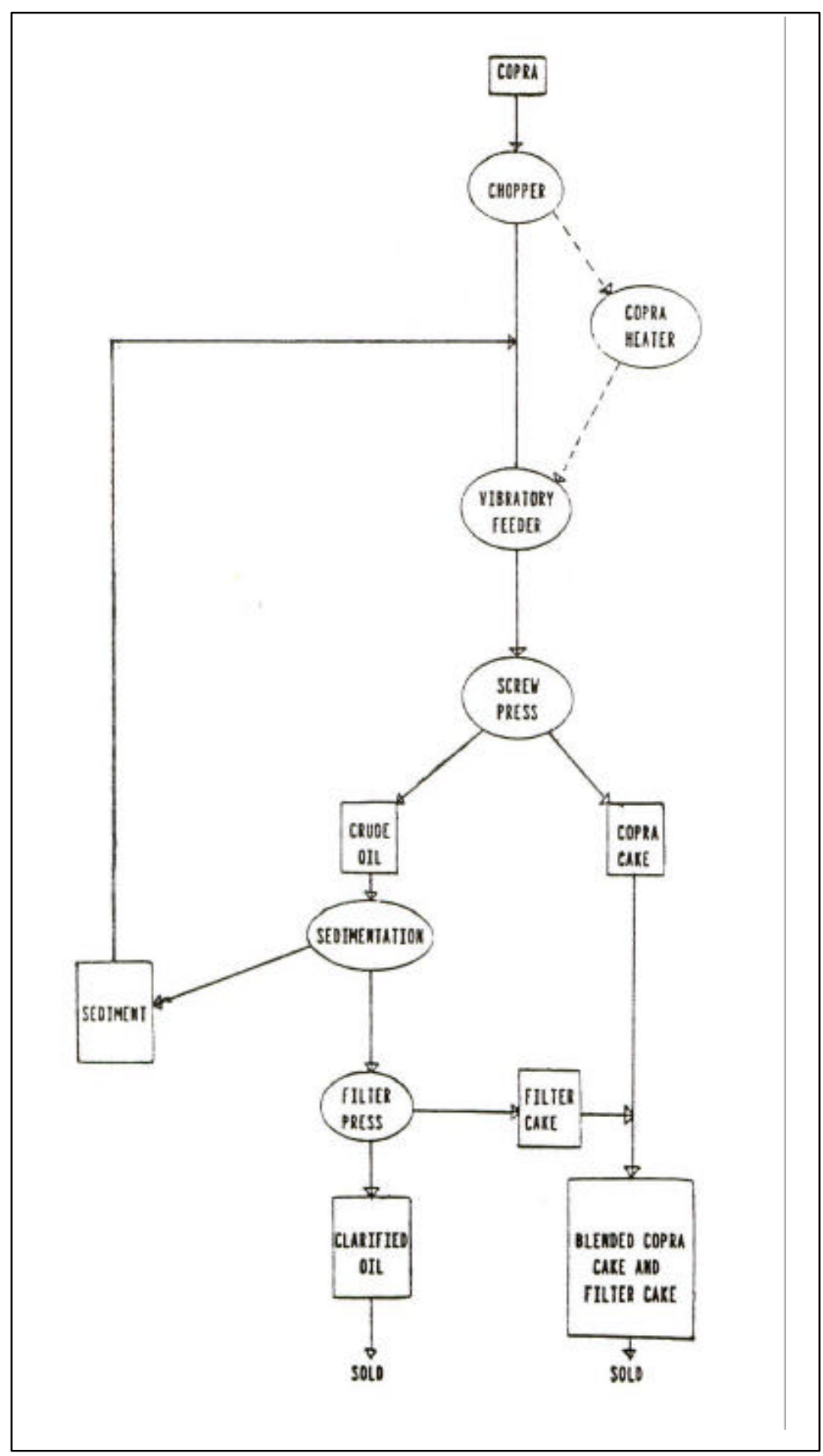


Figure 3. Schedule for Working Day

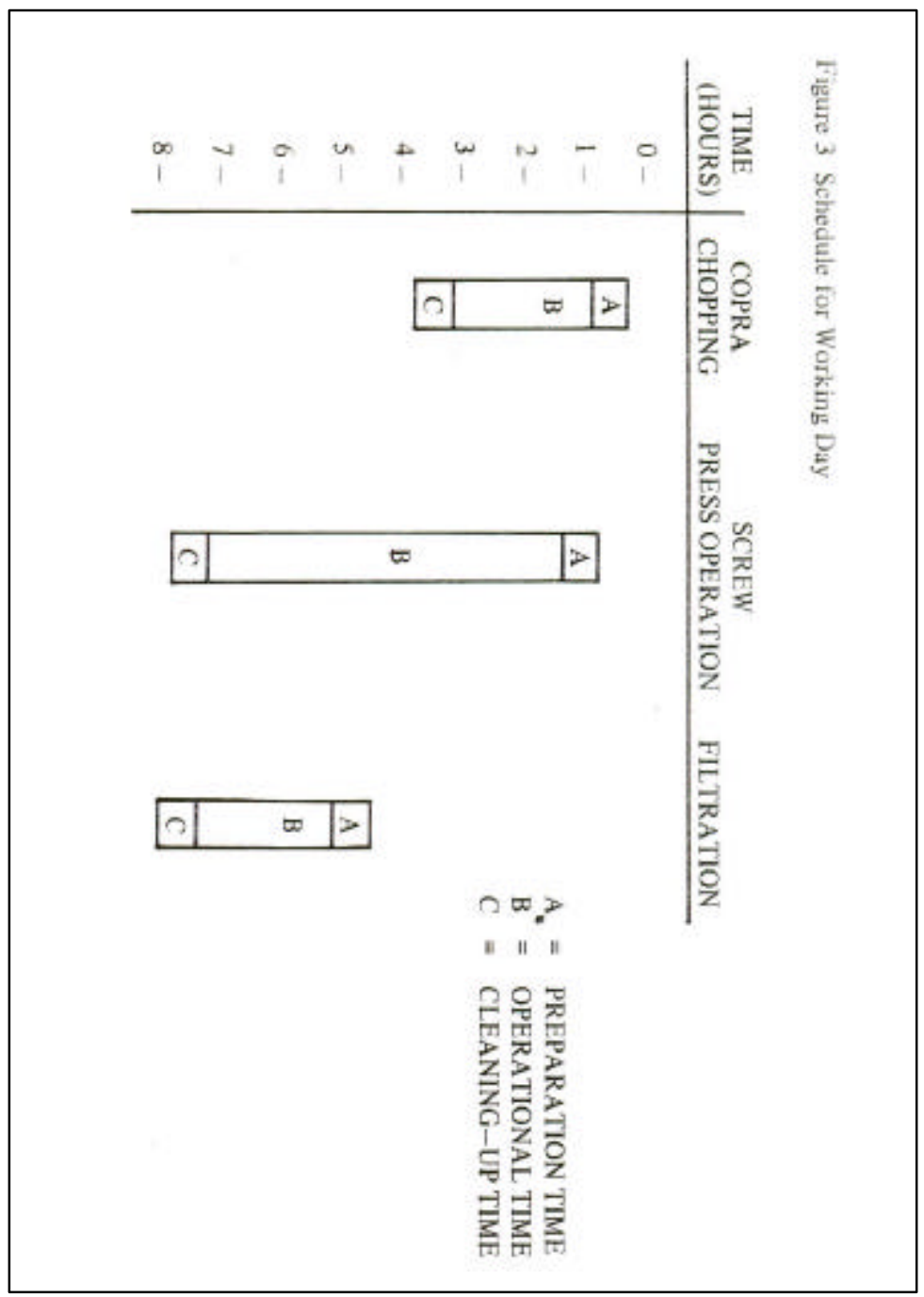

\section{Raw material requirements}

As shown in Table 3, the screw press can handle just under 100 tonnes per year. This volume of raw material is readily available in the Cook Islands, where production of copra has averaged about 1,000 tonnes per year in the 1980s, and is likely to be available also in many other Pacific islands.

Copra must be of a good quality for this type of project, particularly for edible oil production. In large scale processing, coconut oil is normally refined and deodorised before use for edible purposes. In the small-scale process described here, there is no refining stage and therefore quality requirements for the copra are stringent. Fresh copra that has been dried without delay to a moisture content below 6 per cent yields an oil with a fine coconut flavour, a pleasant aroma and low acidity (typically below 0.4 per cent). Oil from old copra tends to have a stale flavour and higher acidity levels. Mouldy copra. should be avoided.

Copra which is not of sufficiently good quality for making edible oil, perhaps owing to some minor mould covering or the age of the copra, may be suitable for cosmetic oil production. Copra of even lower grade can usually be used for the production of oil for soap making. 
In the Cook Islands normal export-quality copra was hand selected for premium-grade copra for edible oil production. Other Pacific islands should have no particular difficulty in producing copra of an appropriate quality. Where, as in the Cook Islands, there is no grading of copra, it may be worthwhile to consider introducing a scheme to pay a premium price for higher quality copra, which would yield a better quality edible coconut oil.

\section{The marketing of coconut oil}

\section{Coconut oil for edible uses}

The aim of the project was to produce coconut oil for edible use, as a substitute for imports of cooking oil. This end-use should yield much more revenue than using the oil for soap-production.

Many Cook Islanders keep pigs and commonly prepare their own lard for use in cooking. Imported vegetable cooking oils, principally soya bean oil, are also widely used; imports are estimated to be in the region of 45,000 litres per year. There is no traditional use of coconut oil in cooking, although the taste of coconut is basic to Polynesian cooking: many types of food are prepared by cooking in home-prepared fresh coconut crearn and coconut sauces are often added to foods after cooking. In other parts of the world coconut oil is highly acceptable as a cooking oil, so one of the aims of the present project was to investigate the scope for marketing coconut oil as a cooking oil in the Cook Islands.

A batch of coconut oil which had an acidity of about 0.35 per cent was prepared using the small-scale screw press. This oil was used in a consumer survey carried out covering 104 households, representing a 5 cer cent sample of the households on Rarotonga. Each household was given two litres of coconut oil for domestic cooking over a one week period. Consumers filled in a daily diary recording how they used the oil and their observations on its acceptability. At the end of the week, an interviewer visited each household and filled in a more detailed questionnaire in cooperation with the householder.

The main result of the survey concerned the degree to which consumers would change to purchasing coconut oil instead of their present cooking oil, if coconut oil was available in the Cook Islands at a price slightly below that of imported soya bean oil. On one hand, 48 per cent of respondents indicated that they would buy coconut oil in preference to their present oil, including 35 per cent who would still continue to buy some of their present oil. On the other hand, 32 per cent would mainly buy their present oil but would purchase also some coconut oil. Only 20 per cent said they would not buy coconut oil at all. In round figures, it would appear that approximately 50 per cent of present consumption of imported cooking oil in the Cook Islands can be substituted by locally produced coconut oil, if priced competitively.

The acceptability of unrefined coconut oil as a cooking oil in other Pacific islands where there is similarly no tradition of consuming this particular product thus appears reasonably promising. Market penetration in the long run cannot be assessed alone on the basis of the type of exercise described above. Tastes in a population can change considerably over time, particularly as consurners become accustomed to a particular product, and consumption pattems can be affected by advertising and other forms of promotion.

(b) Coconut oil for soap manufacture

Assuming a potential for 50 per cent substitution of current imports of cooking oil by locally produced coconut oil, the market in the Cook Islands for coconut cooking oil (22,500 litres per year) would not be sufficient to absorb the output of the smallscale screw press $(56,700$ litres per year) at 
fuII throughput. This partly reflects the small population in the Cook Islands in many other Pacific Islands where, similar ventures could be considered, this situation would probably not arise. However, it is necessary to look at altematives to marketing the coconut oil for edible uses, and the major option is for soap manufacture.

Coconut oil is very suitable, for soap manufacture, making a soap which characteristically foams well (even in salt water), and has a very strong cleansing action. This is ideal as a laundry soap, and coconut oil also makes an acceptable toilet soap. Up to 30 per cent coconut oil can also be used with tallow or lard, to give a milder toilet bar formulation.

The Cook Islands, in common with many other Pacific islands, import large quantities of soap, each year, which in principle could be substituted by soap, manufactured locally wholly or partly from coconut oil. The Cook Islands import about 70 tonnes of soap (excluding detergents) each year, of which about one half is laundry soap in $400 \mathrm{~g}$ retail bars, and the other half is toilet soap in smaller bars. There is also a requirement for guest soaps ( $20 \mathrm{~g}$ bars $)$ in the hotels.

At the outset of the field work for this project, soap was not being manufactured on a significant scale in the Cook Islands. By the end of the visit a local entrepreneur had set up simple facilities for the production of soap in $70 \mathrm{~kg}$ batches using a simple 'cold' process (6).

\section{(c) Coconut oil for other uses}

The use of coconut oil as a hair and body oil is traditional in the Cook Islands, and there is also a market for sun tan oils for sale to tourists. In the Cook Islands, total sales in this category probably amount to about 1,000 litres per year, which is small in comparison with the potential market for coconut oil as a cooking oil or for soap manufacture, and small in comparison with the annual output of the small-scale screw press. Nevertheless, this may be a significant part of the overall market for coconut oil, given the potentially high prices for cosmetic oils.

The Cook Islands import in the region of 800,000 litres of diesel per year. From a technical viewpoint, fuels could be produced from coconut oil as a substitute for diesel. However, the current landed price for diesel is less than 25 per cent of the minimum price necessary to make small-scale coconut oil production viable, so that this option can be dismissed on financial grounds.

\section{The marketing of copra cake}

Imports of animal feeds and ingredients are significant for many Pacific islands, the Cook Islands imported 352 tonnes of feeds and ingredients in 1982 and 981 tonnes in 1983 (the latest available statistics). Most of these feeds are used for pig production and copra cake can be incorporated in pig rations up to 40 per cent of the feed, provided it is blended with other feedstuffs to provide a properly balanced diet.

At full throughput, the small-scale screw press will produce about 39 tonnes of copra cake per year, which could be easily absorbed by the local livestock industry. Cake produced during the demonstration trials in the Cook Islands was sold to farmers in $25 \mathrm{~kg}$ sacks at a price of $28 \mathrm{NZ}$ cents per $\mathrm{kg}$, compared with a landed price for imported pig feed pellets at $64 \mathrm{NZ}$ cents per $\mathrm{kg}$. All copra cake produced was sold as soon as it became available, and farmers were very pleased with the product.

\section{Financial evaluation of small-scale copra expelling}


The financial profitability of small-scale copra processing lias been investigated by an analysis based largely on the actual costs and production data relating to the plant set up and operated in the Cook Islands. Detailed tables and notes relating to the financial analysis are provided in Appendix 1. The analysis is based upon prices and excliange rates in autumn 1986.

\section{Establishment costs}

The fixed capital costs for setting up a small-scale screw press unit total just under NZ \$ 100,000, as shown in Table A.1. Of this total, approximately 50 per cent is accounted for by the landed cost of the equipment. The allowance for land and buildings, estimated at NZ\$35,000, would be higher if actual purchase of land were involved, as opposed to leasing, which is the normal situation in the Cook Islands. The establishment costs of the project arc reduced significantly where the copra processing equipment can be set up in an existing building, and the effect of tWs option of financial performance is discussed later. The project has been costed excluding a seed beater, as this itern of equipment proved unnecessary in the Cook Islands. At locations where copra has a high moisture content, a copra heater may prove advantageous.

\section{Working capital}

Table A.2 gives a breakdown of the working capital requirements for the project, which are about NZ\$12,500 to cover salaries, utilities and other consurnables, plus money tied up in working stocks of copra, coconut oil and copra cake. This is low in relation to the annual turnover of the project, as working stocks of raw material and products will not need to be large for a small project serving local markets.

Operating costs

Total operating costs are just under NZ \$ 85,000 per year.

Fixed operating costs (Table A.3), ie those which are independent of the level of throughput on the equipment, amount to just over NZ $\$ 27,000$ per year, mainly represented by staff costs. Dayto-day operation of the plant requires three workers, one of whom would be semi-skilled and responsible for overall production. Some higher level management will be necessary, but not as a fulltime post. For the present analysis, it is assurned that someone of middle-management calibre would be providing an input averaging one day per week.

Throughput-dependent operating costs (Table A.4) amount to just over NZS 57,000 per year at a throughput of 94.5 tonnes per year, Most of this is represented by purchase of copra, totalling NZ\$ 47,250 per year at a price of NZ\$ 500 per tonne. In the Cook Islands, copra price is stabilised through the operation of a stabilisation fund. The price of NZS 500 per tonne is higher than the official price, to incorporate a premium to encourage supply of higher grade raw material.

Revenue

At full capacity (six hours per day screw press operation), it is estimated that the plant will produce 56,700 litres of coconut oil and 38.7 tonnes of copra cake per year. Revenue from sale of coconut oil will depend on the proportions of output wWch are sold as cooking oil. and for soap manufacture, and the prices that can be obtained for each type of product. The analysis presented here is based on the specific situation in the Cook Islands, which will not necessarily be applicable on other Pacific islands.

Sales of coconut oil for cooking purposes are estimated at 22,500 litres per year, representing 50 per cent substitution of present imports of vegetable oils, and just under 40 per cent of the output of 
the small-scale screw press. It is assurned that the oil is sold wholesale ataprice of NZS 2.25 per litre, excluding bottling costs. This is significantly below the present landed price for imported oils.

The balance of coconut oil, some 60 per cent of the output of the screw press, is assurned to be sold for soap manufacture, for which a price of NZ\$ 1.75 per litre is estimated. At this price, a laundry soap could be produced for a price lower than the present landed cost of imported soap.

Copra cake is assumed to be sold at a price of NZ\$280 per tonne. At this price level, copra. cake produced during the field trials in the Cook Islands sold easily to pig farmers.

With these specific assumptions, the project would generate an annual revenue of NZ\$ 121,324 per year, as shown in Table A.5.

\section{Discounted cash flow analysis}

Table A. 6 presents a cash flow for the project, assuming a ten year life for the equipment, and allowing for replacement of the diesel engine in years 4 and 7 of the project. After the first year, there is a subsequent positive cash flow during the remainder of the project life, with a payback period of just over 2 years. The financial intemal rate of return (IRR) of the project is 49 per cent, and at a discount rate of 10 per cent the project has a net present value of NZ\$131,633.

This analysis shows that small scale copra processing should be a very profitable activity, if carried out under the specific circurnstances assumed to exist in the above model of the project.

\section{Sensitivity analysis}

Many of the assumptions and estimates used above will. not be directly applicable at other potential locations for small-scale copra processing. It is therefore important to identify those cost and revenue items which arc most critical to the financial performance of the project.

Revenue variation is probably the most important item to be considered, and will depend on the average price at which the coconut oil is sold, and the total volume of sales. Average price will depend on the relative sales of oil for cooking purposes versus soap manufacture. The size of the domestic market and the degree of penetration by coconut oil will determine the level of output at which the equipment can be operated; equally, throughput could possibly be reduced or increased for technical reasons.

Table A. 7 shows the effect on the project IRR of varying the average price at which the coconut oil is sold, in relation to varying the throughput on the equipment. The fmancial performance of the project appears fairly robust. In the basic project model presented above,, the average selling price for coconut oil is about NZ\$ 1.95 per litre, and in this price range the project could tolerate a 30 per cent reduction in throughput and remain viable. Equally, at full throughput, the average price could drop as low as NZ\$ 1.60 per litre and the venture is still profitable, other assumptions remaining unchanged.

If all of the output could be sold as cooking oil, at a price near to NZ\$2.20 per litre, small-scale processing is viable even when throughput is reduced by 40 per cent. Table A.7 also shows that even if no oil is sold for cooking purposes, the project is viable producing coconut oil for soap, manufacture alone, providing the plant is-operated close to full capacity.

Capital costs are likely to vary from place to place, particularly in relation to the cost of land and a building. Where the processing equipment can be set up in an existing building such that land and building costs are not incurred, the profitability of the venture improves considerably, as land and 
building account for almost 37 per cent of the capital costs in the basic project model presented above. General variation in capital costs is likely through exchange rate variations (for the imported items), differences in location and other factors. Even with a 20 per cent increase in capital. costs, the project remains profitable.

The operating costs most likely to vary to an extent that would affect the project's viability are the cost of copra and staff costs; the project remains viable even with a 20 per cent increase in either of these items.

While the project as modelled on the Cook Islands appears very attractive and financially sound, circumstances in other locations may be appreciably different. The analysis presented in this paper provides a framework for the assessment of similar projects at other locations.

\section{Economic analysis}

The main economic benefits to Pacific islands like Rarotonga of small-scale copra processing are as follows :

(i) Net foreign exchange benefit arises as the foreign exchange saved by substitution of current imports of vegetable oils and animal feeds outweighs the eamings foregone from copra export. Additional foreign exchange benet-its may result from local soap manufacture.

(ii) Creation of a domestic market for copra improves the stability of demand for the output of copra producers, and therefore should help to stabilise their income.

(iii) Consumers benefit through the availability of cooking oil and/ or soap at a lower price than current imports.

(iv) Employment generation includes not only those directly involved in the copra processing operation, but also those employed in providing services to the project, and downstream industry (such as soap manufacture).

(v) Availability of copra cake at a lower price than imported animal feed ingredients should stimulate the livestock sector.

\section{Summary}

The small-scale processing of copra has been demonstrated and evaluated in the Cook Islands, with a view to examining the potential transfer of this technology elsewhere.

The oil extraction equipment, comprising a knifemill for chopping the copra, a seed heater, a continuous screw press, and a filter press, processed copra very satisfactorily, with few technical difficulties. The seed heater was found to be unnecessary, since the locally available copra (moisture contents 4.3 per cent and 5.3 per cent) did not need heat pretreatment for the particular model of screw press employed. Throughputs in the range of 60 to $70 \mathrm{~kg}$ of copra per hour were consistently achieved, with yields of clarified oil and copra cake around 55 per cent and 40 per cent respectively, on a weight basis. Operating along commercial lines, with a full time staff of three, this set of equipment could process 94.5 tormes of copra per year (250 working days on a single 8 hour shift basis) to produce about 57,000 litres of clarified coconut oil and 38 tormes of copra cake.

Potential markets for coconut oil and copra cake were also assessed, and a consurner survey carried out on Rarotonga indicated that the oil was widely acceptable for cooking purposes. It was 
estimated that locaRy produced coconut oil could substitute for approximately 50 per cent of current imports of cooking oil if marketed at a slightly lower price. An additional potential market was, identified in "cold process" soap manufacture. The production of trial batches of soap led to an entrepreneur taking steps to establish a soap production venture. The copra cake sold readily to local pig farmers.

A basic economic model was developed using the production and cost data obtained during the project and assurned that suffi ciently large markets for the outputs of the equipment could be developed to permit full capacity utilisation. This showed an intemal rate of return of 49.0 per cent, with a payback period of just over 2 years on an initial establishment cost of just'Under NZS 100,000. This represents an attractive investment opportunity in the Cook Islands.

The overall conclusion is that small-scale copra processing is highly feasible from a technical viewpoint, using the equipment tested in the Cook Islands. Provided the output from the project can be marketed, as appears promising on the basis of this study, this type of project can be a highly profitable venture on a Pacific island such as Rarotonga. The analysis presented in this paper is based specifically on the circumstances prevailing in the Cook Islands in late 1986, but the project appears to remain financially worthwhile even with pessimistic assumptions about revenue, or when cost projections are increased within plausible limits. The potential appears promising for identifying other locations where this type of project would be viable.

\section{Acknowledgments}

The authors acknowledge the valuable support in undertaking the work in the Cook Islands provided by Mr. W Hosking, Permanent Secretary in the Cook Islands Ministry of Agriculture, and his staff. Mr A Turua of the Cook Islands Statistics Department assisted in the design and execution of the consumer survey. The production and clemonstration trials were carried out at the Kia Orana Food Corporation factory in Rarotonga, with the cooperation of Mr M Benns, Managing Director, and his staff. Mr K Southwell of TDRI provided technical assistance both in the Cook Islands and in the UK. 
${ }^{1)}$ This work was funded by the United Nations Industrial Development Organisation. Individuals or organisations who consider that small-scale copra processing, as described in this paper, might have potential in their locality and would be interested in having a techno-economic study carried out are invited to write to Mr H Koenig, UNIDO, PO Box 300, A1400 Vienna, Austria.

\section{References}

1. Thieme, J.G. (1968) Coconut oil processing. FAO Agricultural Development Paper No. 89, Rome, FAO.

2. Flynn, G. (1973) An economic study of lauric oilseed processing. Report G81, Tropical Products Institute, London.

3. ILO (1983) Small scale oil extraction from groundnuts and copra. Technical memorandum No. 5, International Labour Organisation, Geneva.

4. Hammonds, T.W. and Smith, A. (1987) An industrial profile on small scale expelling of vegetable oil, Report G202, Tropical Development and Research Institute, London.

5. Hammonds, T.W., Harris, R.V. and Macfarlane, N. (1985) The small scale expelling of sunflowerseed oil in Zambia. Appropriate Technology Journal, 12, No. 1, 217-28.

6. TDRI (1979) Leaflet on 'cold' process soap manufacture.

APPENDIX: Tables relating to the financial analysis

TABLE A.1

FIXED CAPITAL COSTS (1)

\begin{tabular}{|c|c|c|c|}
\hline & Sterling & $\mathrm{NZ} \$(6)$ & Note \\
\hline 1. Land (purchase or lease)...... & 1667 & 5000 & (2) \\
\hline 2. Building $\ldots \ldots \ldots \ldots \ldots \ldots \ldots$ & 10000 & 30000 & (3) \\
\hline 3. Screw press..................... & 3159 & 9477 & \\
\hline 4. Ancillary equipment............ & 800 & 2400 & \\
\hline 5. Diesel engien................... & 1089 & 3267 & \\
\hline 6. Initial stock of spares.......... & 1700 & 5100 & \\
\hline 7. Copra breaker................. & 2100 & 6300 & \\
\hline 8. Ancillary equipment........... & 200 & 600 & \\
\hline 9. Filter press................... & 4500 & 13500 & \\
\hline 10. Stock of filter cloths........... & 700 & 210 & \\
\hline 11. Avery weighing scale......... & 500 & 1500 & \\
\hline 12. Office equipment................ & 500 & 1500 & (4) \\
\hline 13. Tools and lab equipment....... & 500 & 1500 & (4) \\
\hline 14. Carriage and freight........... & 2200 & 6600 & \\
\hline 15. Installation................... & 1000 & 3000 & (4) \\
\hline 16. Contingency allowance........ & 1832 & 5495 & (5) \\
\hline Total Fixed Capital Costs......... & 31816 & 95449 & \\
\hline
\end{tabular}

Notes

(1) Except where otherwise specified, costs arc based on actual costs (in late 1986) for the equipment as installed in the Cook Islands. 
(2) In the Cook Islands, the systern of land tenure is complicated. For this analysis, lease of land is assumed rather than purchase. Team estimate based on discussions with local solicitors.

(3) Based on 100 sq ni at NZ S 300 per sq m as estimated by Ministry of Works.

(4) Team estimate.

(5) Contingency allowance, calculated as $10 \%$ on items 3 to 15 , to cover minor items not specified in the table.

(6) Exchange rate $£ 1=N Z \$ 3.00$.

TABLE A.2

WORKING CAPITAL REQUIREMENTS

\begin{tabular}{|c|c|c|c|}
\hline & NZ\$ & $\begin{array}{c}\text { Allowance } \\
\text { For }\end{array}$ & Note \\
\hline Fixed operating costs ........... & 4563 & 2 months & (1) \\
\hline Utilities......................... & 230 & 3 months & (2) \\
\hline Other consumables.............. & 1000 & fixed sum & (3) \\
\hline Raw material.......... & 1890 & 10 days & (4) \\
\hline Coconut oil in stock............. & 4419 & 10 days & (5) \\
\hline Copra cake in stock........... & 434 & 10 days & (6) \\
\hline TOTAL $\ldots \ldots \ldots \ldots \ldots \ldots$ & 12536 & & \\
\hline
\end{tabular}

Notes

(1) See Table A.3.

(2) See Table A.4.

(3) Team estimate.

(4) Copra, valued at NZ\$500 per tonne, landed Rarotonga.

(5) Coconut oil valued at a weighted average (39.7: 60.3) of the prices for cooking oil (NZ\$2.25 per litre) and for soap manufacture (NZ\$ 1.75 per litre).

(6) Copra cake valued at NZ\$280 per tonne.

TABLE A.3

FIXED OPERATING COSTS

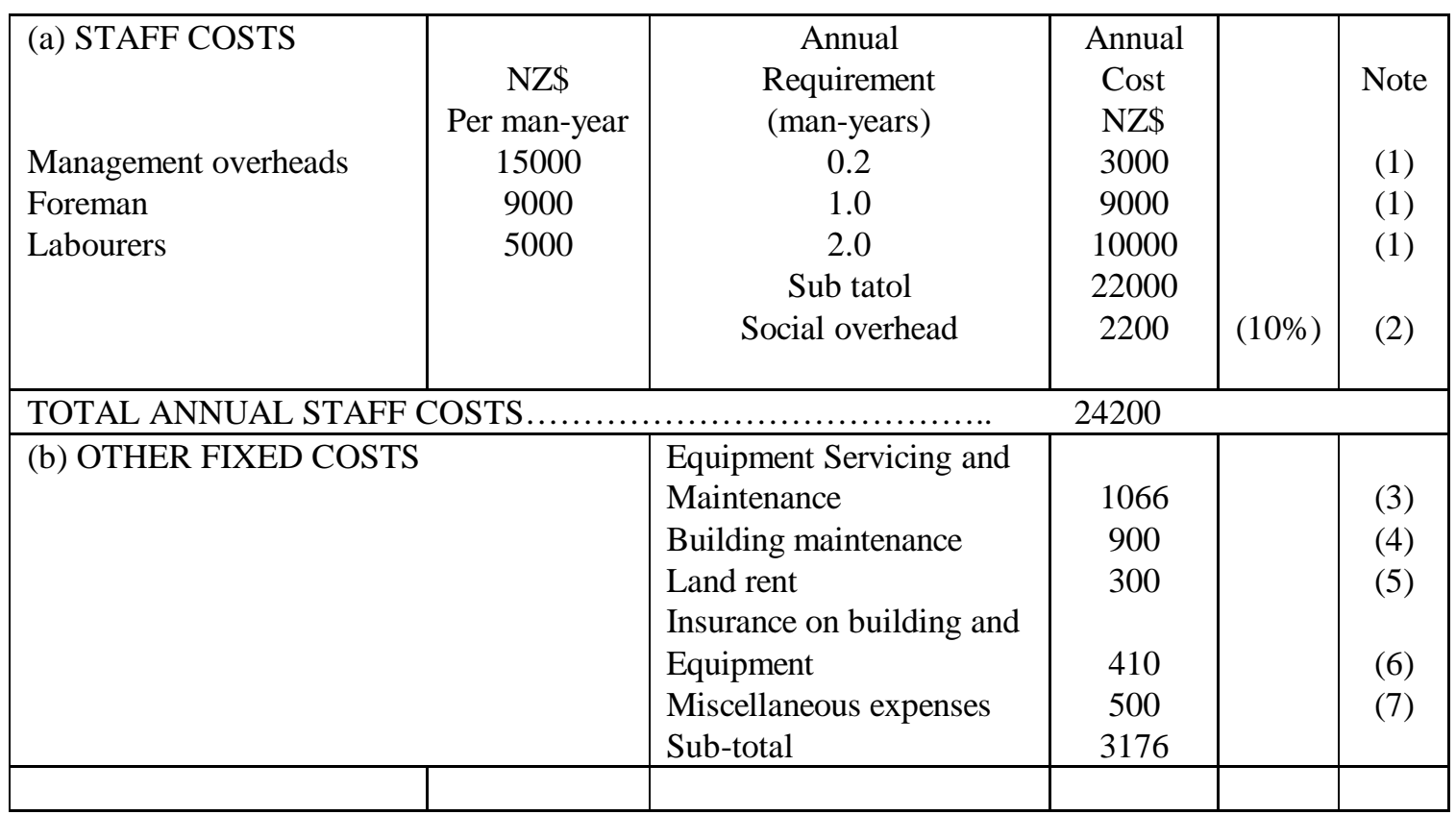




\begin{tabular}{|l|c|c|}
\hline \multicolumn{1}{|c|}{ Sub-total } & 110475 \\
Copra cake & 10849 & \\
\hline TOTAL REVENUE $\ldots \ldots \ldots \ldots \ldots \ldots \ldots \ldots \ldots \ldots \ldots \ldots \ldots \ldots \ldots \ldots \ldots \ldots \ldots \ldots$ & 121324 NZ \$ per year \\
\hline
\end{tabular}

TABLE 6

DISCOUNTED CASH FLOW ANALYSIS

\begin{tabular}{|c|c|c|c|c|c|c|c|c|c|c|}
\hline & 1 & 2 & 3 & 4 & 5 & 6 & 7 & 8 & 9 & 10 \\
\hline Fixed capital costs (2) & $(9544)$ & & & (4133) & & & (4133) & & & 15000 \\
\hline Working capital costs (2) & (12536) & & & & & & & & & 12536 \\
\hline Total operating costs (3) & (84848) & (84848) & (84848) & (84848) & (84848) & (84848) & (84848) & (84848) & (84848) & (84848) \\
\hline Revenue (4) & 121324 & 121324 & 121324 & 121324 & 121324 & 121324 & 121324 & 121324 & 121324 & 121324 \\
\hline Annual net cash flow & (71509) & 36476 & 36476 & 32343 & 36476 & 36476 & 32343 & 36476 & 36476 & 64012 \\
\hline Cumulative net cash flow & (71509) & (35033) & 1443 & 33786 & 70262 & 70262 & 139081 & 175557 & 212033 & 276045 \\
\hline Discount rate: & $18 \%$ & $16 \%$ & $14 \%$ & $12 \%$ & $10 \%$ & $8 \%$ & $6 \%$ & $4 \%$ & $2 \%$ & 0 \\
\hline Net present value: & 74245 & 85703 & 98868 & 114052 & 131633 & 152076 & 175947 & 203950 & 236954 & 276045 \\
\hline
\end{tabular}

Notes

(1) See Table A.1 Replacement of the diesel engine in years 4 and 7 incures a cost of NZ $\$ 4,133$ in each of these years. In the final year of the project, 50 per cent of the initial cost of the building is recovered.

(2) Ses Table A.2. All working capital is recovered in the final year of the project.

(3) See Table A.3 and A.4. Assumed constant throughout the project life.

(4) See Table A.4. Assumed constant throughout the project life.

TABLE A.7

EFFECT OF VARIATION IN THROUGHOUT AND AVERAGE COCONUT OIL PRICE THE PROJECT IRR (1)

\begin{tabular}{|r|r|r|r|r|r|r|r|r|r|r|r|r|r|}
\hline \multicolumn{10}{|l|}{ Throughout } & \multicolumn{10}{|c|}{ Average coconut oil price (NZ\$ per litre) } \\
\hline \multicolumn{1}{|r|}{$\%$} & \multicolumn{1}{|c|}{ /yr } & 1.40 & 1.50 & 1.60 & 1.70 & 1.80 & 1.90 & 2.00 & 2.10 & 2.20 & 2.30 & 2.40 & 2.50 \\
\hline 120 & 113.4 & 5.1 & 16.0 & 27.5 & 40.0 & 54.4 & 71.3 & 91.9 & 117.7 & 151.2 & 196.4 & 260.9 & 360.3 \\
110 & 104.0 & $(0.3)$ & 9.8 & 20.0 & 30.9 & 42.8 & 56.3 & 72.1 & 91.1 & 114.4 & 143.9 & 182.4 & 235.0 \\
100 & 94.5 & $(5.9)$ & 3.6 & 12.8 & 22.3 & 32.3 & 43.2 & 55.6 & 69.8 & 86.5 & 106.6 & 131.3 & 162.4 \\
90 & 85.1 & $(12.0)$ & $(2.9)$ & 5.7 & 14.0 & 22.6 & 31.6 & 41.4 & 52.3 & 64.5 & 78.7 & 95.2 & 114.9 \\
80 & 75.6 & - & $(9.8)$ & $(1.7)$ & 5.9 & 13.3 & 20.9 & 28.9 & 37.4 & 46.6 & 56.8 & 68.3 & 81.3 \\
70 & 66.2 & - & - & $(9.7)$ & $(2.6)$ & 4.2 & 10.8 & 17.4 & 23.2 & 31.3 & 38.9 & 47.1 & 56.1 \\
60 & 56.7 & - & - & - & $(11.7)$ & $(5.4)$ & 0.5 & 6.3 & 11.9 & 17.7 & 23.5 & 29.6 & 36.0 \\
50 & 47.3 & - & - & - & - & - & $(10.5)$ & $(5.3)$ & $(0.3)$ & 4.6 & 9.3 & 14.1 & 18.9 \\
& & & & & & & & & & & & & \\
\hline
\end{tabular}

Notes

(1) Values in the table are the project IRR.

Figures in brackets are negative and - indicates a negative IRR outside the calculation range of the Computer program used. 